\title{
Continuation to upper secondary education in Finland: Children of immigrants and the majority compared
}

\author{
Elina Kilpi-Jakonen \\ Department of Sociology, University of Oxford, UK
}

\begin{abstract}
The education of children of immigrants is an important aspect of the integration of immigrant groups into receiving societies. This article focuses on the first transition in the Finnish education system. Two aspects of the transition are analysed: continuation versus dropping out and choice of upper secondary school type (general versus vocational).
\end{abstract}

Results suggest that children of immigrants tend to have a higher probability of dropping out of education at this transition than the majority. However, this can largely be explained by prior school achievement and family resources. Controlling for these, only some first generation groups are left disadvantaged. Second generation students with very low prior school achievement or a father outside the labour force also have an increased risk of dropping out. These dropouts may be seen as discouraged students.

The picture is more positive for choice of general school. After similar controls, most children of immigrants have a higher probability of choosing general school than the majority. The difference is largest for the non-European $2^{\text {nd }}$ generation and for students with below average prior school achievement. Together with the results for dropout, this points to an avoidance of vocational schools by some ethnic minority groups.

\section{Keywords}

Educational transitions, Finland, immigrants, second generation, social background 
Corresponding author: Elina Kilpi-Jakonen, Department of Sociology, Manor Road, Oxford OX1 3UQ, UK. Email: elina.kilpi-jakonen@ sociology.ox.ac.uk

\section{Introduction}

Immigration and the integration of immigrants and their descendants are of evergrowing importance in Europe. For children of immigrants, education is the primary vehicle for integration. The basis for equality between ethnic groups is laid during compulsory education and continued in further education. Whereas those who migrated as adults may face difficulties in the labour market due to their foreign qualifications and less-than-perfect language fluency, their children should not be hindered in this way. However, if children of immigrants do not receive a fair treatment in the educational sphere, they are unlikely to be able to make up for this in the labour market.

Even though education is one of the most pertinent forms of integration for young people, it is by no means the only one; identity formation is another important dimension of integration for young people. Identification with one's own group and the majority has been examined by social psychologists as part of the acculturation and adaptation of immigrant youth (Berry et al., 2006), whereas recent sociological research has highlighted the way that young people's identities have different levels, which are affected by the national, educational and family contexts in which they live (Faas, 2009).

The focus of this article is on the transition from compulsory to upper secondary education. This transition has a significant impact on future employment (on the impact of education for the employment of ethnic minorities, see Heath and Cheung, 2007; Kalter and Kogan, 2006), and in Finland, it has been found that not making the transition immediately, even if it is made later, has a significant negative impact on employment opportunities later in life (Vanttaja and Järvinen, 2004). The transition from compulsory to upper secondary education can also be seen as a stepping stone on the educational career towards higher education and labour market credentials. 
From Europe and North America, there is evidence that children of immigrants are often at an educational disadvantage compared to the majority population. However, recent research suggests that in some cases the continuation of children of immigrants in education, once prior educational performance has been controlled for, is higher than that of the majority population (for reviews of this literature see Heath et al., 2008; Kao and Thompson, 2003). This could indicate that children of immigrants are, to some extent, adjusting for their poorer performance in school by continuing in education for longer. There may also be other reasons driving their continuation decisions, such as expected discrimination in the labour market.

There are at least three reasons why it is interesting to study children of immigrants in Finland. Firstly, Finnish society has consistently been found to be a relatively equal one, where social differences in many spheres are smaller than they are in most other Western countries. In particular, socioeconomic differences in school performance have been found to be relatively small, even though average performance is very high (e.g. OECD, 2004). Moreover, compared to many other countries, educational reproduction from parents to children has been found to be relatively low (Hertz et al., 2007). Overall, social mobility has been found to be comparable to that in Sweden, in other words relatively high (Erola, 2009; Solon, 2002). Therefore, it is interesting to see how children of immigrants fit into this high-achieving, yet equal and open society.

Secondly, the immigration that Finland has experienced differs from that of other Western European countries. Most notably, there is a lack of labour migration, which characterizes the ethnic minority populations in most of these countries, and instead, there is a large proportion of refugees. European refugee populations have not been studied extensively, but given the very different nature of their migration process to that of labour migrants, it is possible that educational outcomes will differ between the children of the two groups.

Finally, given the relatively recent nature of immigration to Finland, there is still the opportunity for Finland to learn both from other countries and from its own short history in terms of devising effective educational policy. Moreover, new immigrant countries have been seen as having more difficulties in integrating their migrant 
populations than old immigrant societies (Levels and Dronkers, 2008; OECD, 2006). As Finland is a new immigration country, it is important to examine whether it is also experiencing these kinds of difficulties.

The main groups that have migrated to Finland recently have come from Russia (26 $\%$ of the foreign-born population in 2004, including those born in the former Soviet Union), Estonia (7 \%, some Estonians also amongst those born in the former Soviet Union), Sweden (18\%), Somalia (3\%) and areas of the former Yugoslavia (4\%) (Statistics Finland, 2010). As can be seen from this list, the major immigrant groups in Finland consist of citizens of neighbouring countries on the one hand and refugees on the other. Many immigrants from Russia and Estonia have been entitled to immigrate as descendants of ethnic Finns, mostly Ingrian Finns (for more information, see De Tinguy, 2003). Most immigrants from Somalia and exYugoslavia have arrived as refugees, asylum seekers or through family reunification. Amongst the ex-Yugoslavs, the largest ethnic groups are Albanians from Kosovo and Bosniaks, both groups being largely Muslim. On the whole, immigrants have not found it easy to integrate into the Finnish labour market. Rates of labour force participation are lower than for Finns and unemployment rates higher, neither of which can be explained by level of education (Joronen, 2007).

The rest of this introductory section describes the choice that students have to make at the end of compulsory education and some of the implications of this decision, as well as giving a brief overview of previous Finnish research on this topic. This is followed by a discussion of the data and methods used in this article. The sections that follow present the results from the models examining the two parts of the continuation decision, where prior school achievement and family background are used to explain differences between the majority and children of immigrants. The article finishes with a discussion of the results.

\subsection{Upper secondary education in Finland}

Finland has a nine-year comprehensive school system, after which students apply to upper secondary education. Finnish children start school around the age of seven, and 
there is no tracking or streaming in comprehensive schools. Education is compulsory until students either complete the nine grades or have spent ten years in compulsory education. There is a dual system of education at the upper secondary and tertiary levels.

The two types of upper secondary schools in Finland are general upper secondary schools (lukio) and vocational upper secondary schools (ammattioppilaitos or ammattikoulu). Both types take approximately three years to complete and both qualifications give access to tertiary education. Students apply to upper secondary schools during $9^{\text {th }}$ grade and are admitted largely on the basis of their average grade from the comprehensive-school finishing certificate (peruskoulun päättötodistus). Although there are more than enough places to study at upper secondary level for all students to gain a place (Karppinen, 2007), the entry to each course is mainly according to grades. Vocational schools also require non-native speakers to sit a Finnish language examination.

Even though both general and vocational qualifications give access to tertiary education, those who graduate from general schools are much more likely to study in tertiary education. Out of the students who finished general upper secondary in 1998, $37 \%$ were studying in polytechnics and $34 \%$ in universities three years after graduation. On the other hand, out of those who graduated from vocational upper secondary that same year, only $14 \%$ were studying in polytechnics and $1 \%$ in universities three years later. (Statistics Finland, 2007) This probably reflects the wishes of the students for further education to some extent but is unlikely to be the whole story.

Unemployment in Finland is highly stratified according to education (Järvinen and Vanttaja, 2001). Moreover, there is a long-lasting effect of being outside of education and employment at the age of 16-18 on labour force participation, which is still evident in the early thirties (Vanttaja and Järvinen, 2004).

\subsection{Children of immigrants in Finland}


Given the relatively recent nature of immigration to Finland, only one nationally representative piece of research has been published on this topic. This research was done by the National Board of Education (Karppinen, 2008) using data that is very similar to that used in this article. However, their research had a number of limitations that will be addressed in this article.

With regards to dropping out of education after compulsory education, their research found children of immigrants to be more likely to drop out, and the risk was higher for the $1^{\text {st }}$ generation than for the $2^{\text {nd }}$ generation. Within the $1^{\text {st }}$ generation, the risk of dropping out was higher for those born outside the European Union than for those born within it. Differences between groups were found to be partly, although not completely, explained by prior school achievement.

Focusing on those students who continued in upper secondary education immediately after $9^{\text {th }}$ grade, over half continued in general schools (Karppinen, 2008). Nevertheless, the $1^{\text {st }}$ generation was found to be less likely to continue in general schools than the majority, whereas the $2^{\text {nd }}$ generation was more likely. However, the study also found that at each level of achievement, children of immigrants continued to general schools at rates similar or higher than the majority. Therefore, the lower rates of the $1^{\text {st }}$ generation could be explained by their lower prior school performance.

There are several weaknesses with the study quoted above. To begin with, the definition of an immigrant-origin student is based on registered language: all students who are not registered as Finnish- or Swedish-speakers are considered to be of immigrant origin. These students are then divided into the $2^{\text {nd }}$ and the $1^{\text {st }}$ generation depending on whether they were born in Finland or abroad. Whereas this categorisation is likely to correctly identify most of the $1^{\text {st }}$ generation, it is not as appropriate a definition for the $2^{\text {nd }}$ generation. This is because there is a large proportion of students in this category who are members of more established ethnolinguistic minorities and do not have foreign-born parents. This makes it more of a $2^{\text {nd }}$ or higher generation category, although minority students, including the $2^{\text {nd }}$ generation, will only be included in this category if they are not registered as Finnishor Swedish-speakers. Therefore, this group cannot be said to be representative of ethnic minority students. 
In addition to this, within the $1^{\text {st }}$ generation, only a separation between non-EU and EU students is made. This is likely to mask a considerable amount of variation between groups, just as it does in other countries. Finally, the research did not consider the effect of parental resources or household composition on continuation. The importance of these factors will be discussed in the next section.

\section{Theory and research questions}

Family resources have been found to be extremely important for the educational performance of all children. One of the main bodies of theory behind educational continuation is that of rational choice. According to this framework, the main influence behind educational decisions is expectations of payoffs from different educational paths. Beyond differences in abilities, one explanation for the differences between classes in their educational continuation is that their aims are different (Breen and Goldthorpe, 1997): although all children may be assumed to want to minimize the risk of downward mobility, this means that middle class children aim for the middle class whereas working class children aim to minimize the risks of becoming unemployed.

This means that children from lower classes are assumed to be less likely to even attempt a higher level of education in the fear that they might not complete it and would end up with a higher risk of becoming unemployed. In the Finnish case, it is unlikely that attempting to complete the upper secondary level but failing to do so would lead to higher unemployment risks than not attempting it all. Previous research has shown that the chances of ending up unemployed are much higher for those people with only compulsory education compared to any other education level (Järvinen and Vanttaja, 2001), which is likely to be due to the importance that is placed on educational credentials in the labour market. Therefore, we should probably not expect a class gradient in continuation versus dropping out. Nevertheless, a class effect may be present with regards to the choice of general versus vocational upper secondary as the pay-offs from these paths are likely to differ. 
Other theories see the varying educational transition rates of different social groups as stemming from other reasons, such as cultural or informational effects. For example, and in line with standard rational choice approaches, children of more highly educated parents have more information about higher educational institutions as they have attended those institutions themselves. This makes them more confident about their ability to guide their offspring through these institutions successfully.

In this regard, immigrant parents are at a disadvantage if their educational credentials are from foreign educational institutions. In Switzerland and Germany, smaller - even nonexistent - effects of parental education on the educational continuation or attainment of children of immigrants have been found (Bauer and Riphahn, 2007; Gang and Zimmerman, 2000; Kristen and Granato, 2007). In Switzerland, this is driven by the children of low-educated immigrant parents being more likely to pursue higher education than their majority peers, whereas there is no difference between children of high-educated parents (Bauer and Riphahn, 2007). However, there is considerable variation between groups in this regard. On the other hand, Van Ours and Veenman (2003) could not reject the hypothesis that the effect of parental education is the same for the $1^{\text {st }}$ and the $2^{\text {nd }}$ generation compared to the majority in the Netherlands.

Overall, in the Finnish case, it seems that parental resources may be more likely to explain dropping out than expectations of pay-offs. In addition to parental education, relevant factors to look at would therefore be parental income and labour force status. It is also possible that these parental resources do not work in the same way for the children of immigrants as they do for the majority. In particular, having parents who are not employed may be an additional handicap for children of immigrants, as employment is likely to be the main avenue of integration for immigrant adults. Employment can build up both linguistic abilities and social capital for immigrant parents. Therefore, those who are not employed may have even fewer resources to assist their children than native parents in a similar situation.

Monetary resources may also matter for choice of school type. Although in Finland neither the direct costs nor the opportunity costs between vocational and general schools vary much, forward-looking students are still likely to value these two options 
differently in terms of costs. This is because general school is expected to be followed by more education, either in university or in various vocational institutions, in order to have good labour market opportunities. A person who has completed vocational school, on the other hand, is in a better position to enter the labour market immediately after graduation.

In addition to overall family resources, family composition is also likely to be an important factor when resources are considered, both in terms of number of adults giving a resource, but also number of children sharing a resource.

Given that many immigrant groups have, on average, a lower socioeconomic status and lower incomes, sometimes also lower educational levels, it is important to take this into consideration when assessing the impact of ethnic origin on educational continuation.

Prior international research looking at the educational continuation and attainment of children of immigrants has found widespread ethnic minority disadvantage. However, much of this disadvantage is reduced or completely explained by taking into account family background. Moreover, taking into account previous school achievement tends to suggest that ethnic minorities are more likely to continue in education, or at least more likely to continue in the higher tracks of each education level. For example, controlling for grades and social origin, the continuation propensity from Abitur to university in Germany is higher for immigrant-origin students than for the majority, highest of all being for the Turkish-origin group (Kristen et al., 2008). In studies done in France, Sweden and the Netherlands, it has been shown that, after taking into account prior school achievement, at least some groups have higher continuation rates to higher tracks of secondary education than the majority (Brinbaum and CebollaBoado, 2007; Jonsson and Rudolphi, 2009; Van de Werfhorst and Van Tubergen, 2007).

In Germany, a possible interaction has been found between migrant status and grades in going to university (Kristen et al., 2008). This interaction is negative, meaning that grades have a lesser effect for migrants than they do for the majority. Given that, controlling for grades, migrants were found to be more likely to continue in university 
than the majority, this means that their higher continuation is particularly (or only) evident amongst those whose grades are low.

The interaction between immigrant origin and grades could also be positive. This would be the case if children of immigrants were more likely to become depressed by their low grades and thus more likely to drop out (or continue to vocational school). An additional reason why continuation rates for children of immigrants with very low grades may be additionally lowered is the language fluency that is required for vocational studies. This hurdle is likely to be particularly high for students with low grades.

\subsection{Research questions}

This article aims to answer the following questions:

1. To what extent are children of immigrants in Finland disadvantaged in terms of educational continuation?

2. Does this differ between groups and generations?

3. Which family resource measures explain differences between and within groups?

4. What is the effect on between-group differences of taking prior school achievement into consideration?

5. Is the effect of parental resources and prior school achievement the same for children of immigrants as for the majority?

\section{Data and methods}

The data used in this article comes from a data file compiled by Statistics Finland, the national office of statistics. The population for the purposes of this data is all individuals who finished compulsory education in the period 2000-4 and who were resident in Finland in 2004 and 2005. A sample from this population was chosen on the basis of registered language so that $50 \%$ of those registered as foreign-language speakers were included in the sample, as well as $30 \%$ of Swedish speakers and $5 \%$ of Finnish speakers. Although registered language is not the perfect determinant for 
identifying students of immigrant origin, it is nevertheless a relatively good measure for defining the samples. This is because amongst children with two foreign-born parents in 2005, $88 \%$ were registered as foreign-language speakers (Kartovaara et al., 2007). The proportion is close to $98 \%$ when only children who were themselves born abroad are considered, which is the majority of immigrant-origin students in the cohorts studied here.

Ethnic origin is defined on the basis of parental country of birth and generation based on the student's country of birth as well as length of residence. For reasons of anonymity, countries of birth have been grouped together. This was done by Statistics Finland rather than by the author. Naturally, grouping means that the groups used do not, strictly speaking, refer to ethnic groups, although this is often a problem even when the country of origin is known precisely (Jonsson, 2007). Nevertheless, countries have been grouped based on a rough assessment of cultural closeness of countries and should, therefore, approximate ethnic groups.

The $2^{\text {nd }}$ generation is defined as children born to two foreign-born parents who were themselves either born in Finland or had lived in Finland for over nine years prior to finishing comprehensive school. In other words, they should have migrated to Finland before beginning compulsory education. In the migration literature, these students who were not born in the country of origin are often referred to as the 1.5 generation (Suarez-Orozco et al., 2008) or the 1.75 generation (Rumbaut, 2004), but the whole group is referred to as the $2^{\text {nd }}$ generation here. In contrast, the $1^{\text {st }}$ generation are the students who have foreign-born parents, were themselves born abroad and had migrated to Finland less than nine years prior to finishing comprehensive school.

Children with one foreign-born and one Finnish-born parent are analysed as a separate mixed-origin group. These children are sometimes referred to as the 2.5 generation in the migration literature (Rumbaut, 2004). In this article, having countryspecific resources is believed to be an important dimension of socialization (Jonsson, 2007). This means that even one Finnish-born parent should be sufficient for enabling Finnish language acquisition at home as well as having knowledge of the Finnish school system and labour market. However, there may be other processes to do with having one foreign-born parent that may nevertheless disadvantage (or possibly 
advantage) mixed-origin students in the education system. Therefore, those of mixed origin are studied separately rather than merged with the ethnic group of the foreignborn parent. $^{1}$

The ethnic origin groups studied in this article are shown in Table 1. All other immigrant-origin groups are divided into a $1^{\text {st }}$ and $2^{\text {nd }}$ generation except for the exYugoslav group for whom the two groups have been collapsed due to small numbers in the $2^{\text {nd }}$ generation. Based on separate analyses, the two groups do not differ significantly from each other.

[Table 1 about here]

\subsection{Dependent variables}

As described above, there are two possibilities for continuation after comprehensive school as well as dropping out. The possibilities for continuation are general and vocational upper secondary schools. Students' continuation is measured one year after finishing. Table 1 shows the proportion of students within each ethnic group in these three categories.

In this article, the continuation process will be studied with two different binary dependent variables named continuation and choice (see Figure 1). The method used in both cases is logistic regression analysis. First, the continuation versus dropping out process will be analysed. Then, for those who continue, the choice of whether they continue in general or vocational upper secondary schools will be analysed. The main reason for splitting the analyses in two is presentational simplicity. The processes that lead to dropping out are possibly different to those that affect the decisions of what type of school to continue in. For example, many of the students who do not continue may not actively seek to drop out, at least whilst still in school, as dropping out happens most often when students have applied for a place in upper secondary education but have not been accepted (Karppinen, 2007). Therefore, it makes more sense to study these two processes in separate binary logistic regressions 
rather than trying to fit a single (ordered or multinomial) model that would explain both.

[Figure 1 about here]

In order to make the results easily interpretable, and the models comparable, average marginal effects are used to display the results. Average marginal effects display the results of (in this case) logistic regression models as the average effect of a variable on the probability of success. This is done by taking the logistic probability density function at each observation's estimated logit, multiplying it by the coefficient for the variable in question and averaging over all observations (Mood, 2010).

As mentioned, the advantage of using average marginal effects to display the results is that they are more interpretable than odds ratios and also that they are comparable across models. However, the disadvantage is that, as it is a population-averaged estimate, it does not reflect the non-linearity of the relationship that is assumed when using logistic regression models. Therefore, log odds ratios are also included in the tables, as they have these characteristics, but are not comparable across models. (Mood, 2010)

In addition to this, predicted probabilities are used for the results of the models with interactions. The predicted probabilities are calculated using the Clarify program in Stata (King et al., 2000; Tomz et al., 2003).

\subsection{Independent variables}

\subsubsection{Prior school achievement}

The measure of prior school achievement used here is the average of either all grades or just those in 'theoretical' subjects in the comprehensive-school finishing certificate. This is also the main basis on which students are chosen into upper secondary schools. Grades are given in each subject from four (unsatisfactory performance) to 
10 (excellent performance). The mean average grade in this sample is 7.8. Grades are teacher-assigned.

Whether grades are based on all subjects or just the theoretical subjects depends on the type of school the student applied to. General upper secondary schools base entry on the average from theoretical subjects, whereas vocational schools base entry on all subjects. In the registers from which the data comes, students will only have the type of information required by the schools that they have applied to. The effect that this has on the results reported here is possibly to attenuate the estimated effect of grades on continuation somewhat. This is because poorer performing students are more likely to have information on the average of all grades, which is likely to be higher than their average for theoretical subjects, whereas the better performing students are more likely to have information on the more demanding measure.

For anonymity reasons, the very top and very bottom grades have been collapsed in the data, thus giving us a range of grades from 6 to 9.5. There are also some students who have missing information on grades (716 students or $2.3 \%$ of the population). Therefore, in this article, multiple imputation is used to estimate average grades for those students with missing information as well as spread out the collapsed end categories somewhat. The variables that are used to impute grades are gender, ethnic origin and generation, household composition, father's and mother's education, income, socioeconomic status and labour force participation, the student's continuation the following year, as well as a dummy for whether the student is highachieving or low-achieving. These last two dummies are applicable to those in the collapsed groups rather than those with missing grades originally. After imputation, grades are adjusted to range from 5 to 10 , and the grades in the collapsed categories are adjusted not to be above 6 in the low category, or below 9.5 in the high category. Interactions with grades are calculated from the imputed values of grades rather than imputed independently. Ten imputations are used in the analyses for this article. Using multiple imputations rather than a single one takes into account the uncertainty in the estimated grades.

\subsubsection{Family resources}


The measures of family resources used in this article are parental education, parental labour force participation, parental income, parental socioeconomic status and household composition.

For the analyses of choice, a six-category measure of combined parental education is used, whereas for continuation, a binary variable that only measures whether at least one parent has some kind of tertiary education is used. This binary distinction is the main significant difference found in preliminary analyses of continuation. The categories for the combined parental education measure are:

1. Both parents have a university degree;

2. Both parents have at most general upper secondary education or lowest level tertiary education, or at most one parent has a university degree;

3. At most one parent has general upper secondary education or lowest level tertiary education;

4. Parents have at most vocational (upper secondary) education;

5. Parents have at most compulsory education;

6. Both parents' education is unknown.

For people with foreign qualifications, data on education may be completely missing or incorrectly classified. Based on survey data from the Russian, Estonian, Somalian and Vietnamese population in Finland, the proportion of people with upper secondary and lowest level tertiary education is possibly underestimated here and in some groups the proportion with a university degree (Liebkind et al., 2004; Pohjanpää et al., 2003). In order to alleviate part of the problem of missing data, for parents with unknown education but with information on socioeconomic status, their education is replaced with the modal or mean level of education of others with the same socioeconomic status. $^{2}$

Parents' labour force participation is measured separately for mothers and fathers. The categories in this variable are employed, unemployed, outside the labour force and unknown. 
Parental income categories are combined from separate information on mother's and father's quartile of taxable income. The three categories are defined as follows:

1. High: At least one parent earns in the highest quartile, or both parents earn in the third quartile;

2. Medium: At most one parent earns in the third quartile, or both parents earn in the second quartile;

3. Low: At most one parent earns in the second quartile, or both earn less, or both unknown.

Parental socioeconomic status is defined according to the dominance principle. The categories used are based on the Finnish classification of socioeconomic groups (1989) and are the following:

1. Upper-level employees (senior officials and employees, upper management);

2. Lower-level non-manual employees (supervisors, clerical and sales workers), selfemployed and farmers;

3. Manual workers;

4. Outside the labour force and unknown (including students and pensioners).

Household composition combines information on the number of adults and children in the household. The categories separate out households with a single parent versus those with two and those with three or more children versus those with one or two. In addition, a separate category for households where there are no children and thus the student is presumably an adult living on their own is included, although this is combined with those with missing information on household composition.

All other independent variables except for parental socioeconomic status come from registers of the year when the student finished comprehensive school. Socioeconomic status is from the year 2000 for all as this data is produced by Statistics Finland less frequently. For all measures that have been combined or collapsed from separate or more detailed information, alternative specifications were also tested but the ones used here were found to be the most suitable in terms of explanatory power and parsimony. 
As a final note, all of the information about parents relates to the student's biological parents, or adopted parents when information about biological parents is not available. Therefore, the information does not necessarily relate to the adults that the student lives with. Related to this, there may be information about both parents even when the student only lives with one. Only the information about household composition is specifically about the people that the student lives with.

\section{Results}

\subsection{Continuation in education versus dropping out}

The first outcome to be analysed in this article is that of continuing in some form of upper secondary education versus dropping out. The last column of Table 1 is therefore compared to the two next to it. The raw difference from the Finnishspeaking majority can also be seen in Model 1 in Figure 2. Several immigrant-origin groups are more likely to drop out of education than the majority. The group most likely to drop out is the Sub-Saharan $1^{\text {st }}$ generation, for whom the difference with the majority is almost 24 percentage points. Overall, $1^{\text {st }}$ generation groups tend to be more likely to drop out than $2^{\text {nd }}$ generation groups, and non-European groups more likely than European groups. In addition to the immigrant-origin groups, otherlanguage Finns are also more likely to drop out than the Finnish or Swedish speakers.

[Figure 2 about here]

Model 2 introduces the parental resource measures used, Model 3 household composition and Model 4 prior school achievement. The effect of the control variables on between-group differences can be seen in Figure 2 and the full models in Table A1 in the appendix. Having a parent who is not employed tends to increase the probability of dropping out, except for fathers who are outside the labour force. Having at least one tertiary-educated parent reduces the probability of dropping out. Living in a household with only one adult and many children both increase the probability of dropping out, although the number of children does not have a further effect in single-adult households. Those most likely to drop out are the students living 
alone, although they are likely to be a rather different group of comprehensive-school leavers compared to the rest. Prior school achievement has a strong effect on the probability of dropping out, and after controlling for this, girls are more likely to drop out than boys. ${ }^{3}$

The ethnic-origin estimates from the different models that include controls do not differ significantly from each other. Together the controls used here explain most of the differences between immigrant-origin groups and the majority, though not between the other-language Finns and the majority. In addition to the other-language Finns, the groups that remain more likely to drop out after controlling for family resources and prior school achievement are the Sub-Saharan African and East Asian $1^{\text {st }}$ generation. The West Asian and North African and the residual other $1^{\text {st }}$ generation are also marginally more likely to drop out than the majority. The significant differences between these groups and the majority Finns are approximately 4-8 percentage points.

The second set of analyses for continuation versus dropping out concerns interactions between the control variables and immigrant origin. For these analyses, the $1^{\text {st }}$ generation groups are grouped together, as are the $2^{\text {nd }}$ generation groups, and all the Finnish-origin groups, including those of mixed origin. The two interactions that are found to be significant at the $10 \%$ level are for the $2^{\text {nd }}$ generation and father being outside the labour force and average grades (full models in Table A2 in the appendix). Whereas for other groups having a father outside the labour force is no different to having an employed father in terms of dropping out, for the $2^{\text {nd }}$ generation this has an effect in increasing the probability of dropping out. Moreover, the $2^{\text {nd }}$ generation is also more affected by prior school achievement. This tends to translate into a wider gap in dropout rates for the poorer-performing students.

Both of these effects are visible in Figure 3, which shows predicted probabilities of continuing to upper secondary education. Whereas the difference in the effect of grades is relatively small and only significant at the very bottom end of the achievement range, the combined effect of grades and father being outside the labour force is quite striking for the $2^{\text {nd }}$ generation. 
[Figure 3 about here]

Overall, the higher dropout rates of the $2^{\text {nd }}$ generation can be explained by their lower family resources and their lower prior school achievement. However, a disadvantage remains for $2^{\text {nd }}$ generation students with very low grades as well as for those with fathers outside the labour force. Therefore, whilst overall the $2^{\text {nd }}$ generation are not greatly disadvantaged, the general figures hide a highly vulnerable subgroup.

4.2 General versus vocational upper secondary school

The second outcome to be analysed is that of choosing to continue to general versus vocational upper secondary. In other words, the two school columns in Table 1 are compared with each other, and those not continuing at all are dropped from the analyses. Figure 4 displays these analyses (and full models are in Table A3 in the appendix). We can see that most groups do not differ from the majority Finns in their overall probability of choosing general school (Model 1). However, there is some variation around this pattern with the ex-Yugoslavs being least likely to do so: the difference from the majority is 30 percentage points. The Russian and Estonian, SubSaharan African and residual other $1^{\text {st }}$ generation are also less likely to continue to general schools. On the other hand, the Sub-Saharan African $2^{\text {nd }}$ generation and the mixed-origin group are more likely than the majority to do so.

[Figure 4 about here]

Again, Model 2 introduces the parental resource measures used, Model 3 household composition and Model 4 prior school achievement. The parental resource measures have the expected gradients, and parental education seems to have the largest effect. After controlling for prior school achievement, the only household composition category to differ significantly from the two parents, maximum two children reference category is that of two parents and three or more children. In other words, children of single parents are no less likely to continue to general schools than children living with two adults. Controls for grades also turn the positive female effect into an 
insignificant one. The effect of grades on the probability of continuing to general school is rather large compared to the other estimates in the models. ${ }^{4}$

For many minority groups, controlling for family resources makes them significantly more likely to continue in general schools than the majority, and this trend is further strengthened by controlling for prior school achievement. The trend for the students of East Asian origin is slightly different due to their high average school performance. After the introduction of these controls, almost all immigrant-origin groups have a higher probability of continuing to general schools than the majority. The exceptions are the ex-Yugoslavs and the East Asian $1^{\text {st }}$ generation who do not differ significantly from the majority. The group with the highest probability of continuing to general schools is the Sub-Saharan African $2^{\text {nd }}$ generation, who have a 28 percentage point difference to the majority. Other groups tend to differ from the majority by 8-20 percentage points.

As with continuation, interactions are also tested for choice of school type. In this case the $2^{\text {nd }}$ generation is divided into European and non-European as these two groups are found to differ with regards to some of the interactions. The parental education measure is also simplified in order to improve the ability to find statistically significant results. For the European $2^{\text {nd }}$ generation, an interaction is found for parental education (full models in Table A4 in the appendix). This result indicates that, for this group, there is almost no difference between students with parents who have at least general upper secondary education and those who do not. On the other hand, for the non-European $2^{\text {nd }}$ generation and the $1^{\text {st }}$ generation, interactions are found for grades: both of these groups have smaller within-group effects of prior school achievement.

[Figure 5 about here]

All of these interactions are evident in Figure 5 that shows predicted probabilities of continuing to general school. The high probability of choosing general school for the non-European $2^{\text {nd }}$ generation is visible in both panels, and this difference is largest in the medium to low range of the achievement distribution. The $1^{\text {st }}$ generation differs less from the majority, although again, the difference is more evident when 
achievement is below average. On the other hand, the European $2^{\text {nd }}$ generation differs most from the majority when parental education is low.

Overall, children of immigrants tend to be more likely than the majority to choose general schools. This is mainly the case after family resources and prior school achievement have been controlled for. Those most likely to choose general school are the non-European $2^{\text {nd }}$ generation, particularly those of Sub-Saharan African origin. The difference between children of immigrants and the majority tends to be largest towards the lower end of the achievement range.

\section{Discussion}

This article has looked at the two parts of the continuation decision that students have to make at the end of compulsory education. The main findings are that although children of immigrants tend to be more likely to drop out of education at this stage, this can largely be explained by their lower family resources and lower prior school achievement. On the other hand, children of immigrants do not tend to differ much from the majority in terms of their choice between general and vocational upper secondary school. However, after other explanatory factors have been introduced, their probability of continuing to general school tends to be higher than for the majority.

Within this rather straight-forward picture, there are some interesting group differences: for example, a few $1^{\text {st }}$ generation groups remain more likely to drop out of education than the majority, as are the other-language Finns. Further analyses indicate that for the East Asian $1^{\text {st }}$ generation and the other-language Finns, the increased probability of dropout is mainly a male phenomenon whereas it is a female one amongst the Sub-Saharan African $1^{\text {st }}$ generation.

It is possible that the boys from the two groups mentioned above have relatively better opportunities to become employed in 'ethnic' jobs than do boys or girls from other groups. This would mean that they have relatively fewer incentives to continue in education. The dropout amongst the Sub-Saharan African $1^{\text {st }}$ generation girls may 
be explained by a lingering doubt over the value of female education amongst this group, and possibly a greater inclination to get married at a younger age than in other groups. However, it may also be linked to their refugee background and caused by more broken school careers before arrival in Finland. Lack of educational provision is likely to have affected girls disproportionately, thus leaving them with fewer resources to gain a desirable place of study in upper secondary.

The differences between the majority and the children of immigrants are only evident at the very lowest end of the achievement scale. This is linked to the finding that grades have more of an effect for the $2^{\text {nd }}$ generation than for the majority. This interaction means that, controlling for parental labour force status, $2^{\text {nd }}$ generation students are significantly more likely to drop out than the majority when grades are low but no different otherwise.

This result may be explained by the fact that the largest proportion of dropouts amongst children of immigrants are those who applied but did not get in and also did not reapply (Karppinen, 2007). This is likely to be the case for those students with the lowest grades. Moreover, particularly the $1^{\text {st }}$ generation non-EU students (some of whom would be defined as $2^{\text {nd }}$ generation here) have been found to use the opportunities of supplementary applications (jälkivalinta) and $10^{\text {th }}$ grade relatively less than other groups (Karppinen, 2007).

Therefore, the problem is not so much that children of immigrants are actively seeking to drop out of education, but that when faced with the situation that they have not gained a place of study in the main round of applications, they do not have the resources or motivation to seek admittance through other routes to the same extent as other groups of students. This would indicate that the (immigrant-origin) students who drop out are largely discouraged rather than actively anti-school.

An interaction was also found for the $2^{\text {nd }}$ generation with fathers outside the labour force; whereas this did not have a negative effect compared to having an employed father for other groups, it did have a significant negative effect for the $2^{\text {nd }}$ generation. This highlights the importance of immigrant parents' labour market integration: immigrants who are not in the labour force do not obtain the same language skills or 
build the same social networks as those outside it. It is interesting to note that parental unemployment does not have this additional negative impact for children of immigrants. This may be due to Finnish legislation, the consequence of which is that those who are unemployed tend to go on training and language courses and get work experience to a much greater extent than in many other countries. In other words, although long-term employment is more valuable for integration, being unemployed rather than outside the labour force may also assist in integration. Again, the effect of having a father outside the labour force may work mainly at the stage when an initial application has been rejected and the student becomes discouraged from making a new application.

With regards to choice of upper secondary school type, the Sub-Saharan African $2^{\text {nd }}$ generation stands out with their high probability of continuing to general schools, both before and after relevant controls. Overall, the non-European $2^{\text {nd }}$ generation has the highest predicted probabilities of continuing to general schools, and the difference from the majority is particularly large for students with relatively low achievement levels. Together with the result that the $2^{\text {nd }}$ generation is more likely to drop out at low achievement levels, this implies that there is polarization within this group and what seems to be an avoidance of vocational schools.

A possible explanation for the high continuation rates for students of Sub-Saharan African origins is their high visibility, which may lead them to expect the greatest amount of discrimination in the labour market. This in turn may push them to seek higher levels of education. It could also be argued that the high levels of discrimination will eventually lead to their leaving Finland and in that case a general education may be more transferable than a Finland-specific vocational qualification. Overall, children of immigrants may see vocational qualifications as tying them to Finland more than general qualifications and may thus value the latter more highly.

Students originating from ex-Yugoslavia differ from all other immigrant-origin groups in their preference for vocational education. Even though they do not differ significantly from Finns after achievement and family resources have been controlled for, they do differ significantly from most other groups. This peculiarity of the exYugoslav group is not mirrored in Swedish results (Jonsson and Rudolphi, 2009). On 
the other hand, Albanian-speaking ex-Yugoslavs in Switzerland tend to have lower rates of continuation to tertiary education than other groups, including SerboCroatian-speaking ex-Yugoslavs (Fibbi et al., 2007). These differences remain after controls for citizenship, parental education and contextual characteristics of the municipality of residence. The majority of ex-Yugoslavs in Finland are Albanianspeaking, and therefore, the educational choices of this group seem to be similar to the choices of the corresponding group in Switzerland.

For the European $2^{\text {nd }}$ generation overall, the (positive) difference relative to the majority was found to be most evident for those with low parental education. This finding reflects previous international results (Bauer and Riphahn, 2007; Gang and Zimmermann, 2000; Kristen and Granato, 2007). However, no clear explanation exists for this effect, and in the Finnish case, one possible explanation is the potential underreporting (or missing information) of immigrants' education.

Whereas previous models of educational continuation focus on the social class of parents affecting the continuation decisions of their children (e.g. Breen and Goldthorpe, 1997), this was not found to have a significant impact on the continuation decisions of Finnish students. In contrast, for the educational choices of children, parental socioeconomic status and income do have an explanatory effect. In other words, it is only for dropping out that the mechanisms related to more class-based cost-benefit analyses do not seem to be appropriate for. This may be largely due to the Finnish labour market, which penalizes people without upper secondary qualifications heavily.

\section{Conclusion}

In conclusion, structural explanations account for much of the initial disadvantage that many children of immigrants face at the transition to upper secondary education. Moreover, most groups show a significant amount of educational resilience in terms of choosing general upper secondary schools. Despite this rather optimistic picture, a few areas of concern can be raised. 
Firstly, a heightened risk of dropping out exists among students with relatively low achievement levels, particularly among the $2^{\text {nd }}$ generation and especially for those with a father outside the labour force. It seems plausible that immigrant-origin students with low grades who do not gain entry into upper secondary education in the main round of applications become 'discouraged students'. Their resources and lowered motivation are then insufficient to access upper secondary education later. This is a rather different kind of explanation from ones normally put forward for school dropout, which focus on anti-school attitudes. Supporting this vulnerable group of students should be a priority for education professionals.

Higher dropout may be related to the language tests that those registered as foreignlanguage speakers have to take in order to access vocational schools. The necessity of these language tests for those who have attended school in Finnish for several years may be debated. Moreover, the fact that the administration of the test is based solely on registered language gives an incentive for children of immigrants to change their registered language. The processes that lead to dropout amongst children of immigrants are an important area for future research.

At the same time, immigrant-origin students with average to low levels of achievement also have a higher probability of continuing to general school than their majority peers. Although this high level of ambition can be seen as positive, the lower achievement levels that these students enter general schools with highlights their need for additional support in general schools. An important area for future research would, therefore, be completion of upper secondary, focusing in particular on the students who enter general schools with relatively low grades.

The apparent aversion of vocational schools in some immigrant-origin groups could be addressed by more information about the education system for both children of immigrants and their parents. Given the relatively high dropout rates from upper secondary education that have been found in previous research (Karppinen, 2008), this increased information before choices are made could also help students avoid choosing schools or courses that they will not complete. 
The importance of parental labour force participation for continuation and dropout has been highlighted in this article. Students of employed parents, whatever their ethnic origin, are in the best position to continue in education. This is a particularly important conclusion for policy: improving the employment opportunities of immigrants is one of the best ways to increase the educational attainment of their children.

Overall, despite its different migration history, Finland does not seem to differ much from other Western European countries. Children of immigrants display a great deal of educational resilience in terms of their higher continuation propensity to general upper secondary education. It may be that non-European refugee groups have an even higher propensity in this regard. Moreover, with regards to both continuation outcomes considered here, the Finnish education system seems to be relatively beneficial for children of immigrants - but only after taking into consideration their lower family resources and lower prior school achievement.

\section{Notes}

I would like to thank Anthony Heath for his comments and advice. This paper has also benefited from comments from an anonymous reviewer and those received on early versions of this paper at various conferences and workshops, including the Transitions in Youth meeting and ETMU conferences. This research was funded by doctoral training grants from the Economic and Social Research Council, UK (grant number PTA-031-2006-00384) and Kone Foundation, Finland.

${ }^{1}$ There is also a residual 'unknown' group of students for whom no information on countries of birth is known and they are included in the 'other' category.

${ }^{2}$ Either the mode or the mean is used depending on which was judged to be more appropriate. A total of 83 replacements were made to father's education and 25 to mother's education. However, this changed the combined category of only 52 families.

${ }^{3}$ Parental socioeconomic status and parental income were not found to explain dropping out. They have, therefore, been left out of these models. 
${ }^{4}$ Mother's labour force status was not found to predict choice of school, although father's non-employment was found to increase the probability of choosing general school. However, adding this variable did not improve model fit or change the ethnicorigin coefficients, so it was left out of the model.

\section{Biographical note}

Elina Kilpi-Jakonen is a postdoctoral research fellow at the Oxford Network for Social Inequality Research, Department of Sociology, University of Oxford. Her research interests focus on children of immigrants, school effects and gender inequalities in education.

\section{References}

Bauer P and Riphahn RT (2007) Heterogeneity in the intergenerational transmission of educational attainment: Evidence from Switzerland on natives and secondgeneration immigrants. Journal of Population Economics 20(1): 121-148.

Berry J, Phinney J, Sam D and Vedder P (eds) (2006) Immigrant Youth in Cultural Transition: Acculturation, Identity and Adaptation across National Contexts.

Mahwah, NJ: Lawrence Erlbaum Associates.

Breen R and Goldthorpe JH (2001 [1997]) Explaining educational differentials: Towards a formal rational action theory. In: Grusky DB (ed.) Social Stratification: Class, Race and Gender in Sociological Perspective. Boulder, CO: Westview Press, $459-470$.

Brinbaum Y and Cebolla-Boado H (2007) The school careers of ethnic minority youth in France: Success or disillusion? Ethnicities 7(3): 445-474.

De Tinguy A (2003) Ethnic migrations of the 1990s from and to the successor states of the Former Soviet Union: 'Repatriation' or privileged migration? In: Münz R and 
Ohliger R (eds) Diasporas and Ethnic Migrants: Germany, Israel, and Post-Soviet Successor States in Comparative Perspective. London: Frank Cass, 112-127.

Erola J (2009) Social mobility and education of Finnish cohorts born 1936-75: Succeeding while failing in equality of opportunity? Acta Sociologica 52(4): 307327.

Faas D (2009) Reconsidering identity: The ethnic and political dimensions of hybridity among majority and Turkish youth in Germany and England. British Journal of Sociology 60(2): 299-320.

Fibbi R, Lerch M and Wanner P (2007) Naturalisation and socio-economic characteristics of youth of immigrant descent in Switzerland. Journal of Ethnic and Migration Studies 33(7): 1121-1144.

Gang IN and Zimmermann KF (2000) Is child like parent? Educational attainment and ethnic origin. The Journal of Human Resources 35(3): 550-569.

Heath AF and Cheung SY (eds) (2007) Unequal Chances: Ethnic Minorities in Western Labour Markets. Oxford: Oxford University Press.

Heath AF, Rothon C and Kilpi E (2008) The second generation in Western Europe: Education, unemployment, and occupational attainment. Annual Review of Sociology 34: $211-235$.

Hertz T, Jayasundera T, Piraino P, Selcuk S, Smith N and Verashchagina A (2007) The inheritance of educational inequality: International comparisons and fifty-year trends. The B.E. Journal of Economic Analysis \& Policy 7(2): Article 10.

Järvinen T and Vanttaja M (2001) Young people, education and work: Trends and changes in Finland in the 1990s. Journal of Youth Studies 4(2): 195-207.

Jonsson JO (2007) The farther they come, the harder they fall? First- and secondgeneration immigrants in the Swedish labour market. In: Heath AF and Cheung SY 
(eds) Unequal Chances: Ethnic Minorities in Western Labour Markets. Oxford: Oxford University Press, 451-505.

Jonsson JO and Rudolphi F (2009) Weak performance - strong determination: Achievement and choice among ethnic minority students in Sweden. Paper presented at EQUALSOC Conference, Tallinn, June.

Joronen T (2007) Työmarkkinoiden monenlaiset maahanmuuttajanaiset: Haaste suomalaiselle sukupuolijärjestelmälle [Immigrant women in the Finnish labour market]. In: Martikainen T and Tiilikainen M (eds) Maahanmuuttajanaiset: Kotoutuminen, Perhe ja Työ [Immigrant Women]. Helsinki: The Family Federation of Finland, 285-311.

Kalter F and Kogan I (2006) Ethnic inequalities at the transition from school to work in Belgium and Spain: Discrimination or self-exclusion? Research in Social Stratification and Mobility 24(3): 259-274.

Kao G and Thompson JS (2003) Racial and ethnic stratification in educational achievement and attainment. Annual Review of Sociology 29: 417-42.

Karppinen K (2007) Nuorten ongelmat koulutusvalinnoissa ja toiselle asteelle siirryttäessä [Young people's problems in educational choices and at the transition to upper secondary education]. In: Alatupa S (ed.) Koulu, Syrjäytyminen ja Sosiaalinen Pääoma - Löytyykö Huono-osaisuuden Syy Koulusta vai Oppilaasta [School, Marginalisation and Social Capital]. Helsinki: Sitra, 122-139.

Karppinen K (2008) Koulumenestys, koulutukseen valikoituminen, tutkinnon suorittaminen ja työelämään siirtyminen [School achievement, continuation, degree completion and entry into the labour market]. In: Kuusela J, Etelälahti A, Hagman A, Hievanen R, Karppinen K, Nissilä L, Rönnberg U and Siniharju M, Maahanmuuttajaoppilaat ja Koulutus - Tutkimus Oppimistuloksista, Koulutusvalinnoista ja työllistämisestä [Immigrant Students and Education]. Helsinki: National Board of Education, 135-186. 
Kartovaara L, Niskanen T, Rautanen R, Reijo M and Sauli H (2007) Vieraskielisten lasten elinolot [The living conditions of foreign-language children]. In: Statistics Finland and Stakes (eds) Suomalainen Lapsi 2007 [The Finnish Child 2007]. Helsinki: Statistics Finland and Stakes, 411-431.

King G, Tomz M and Wittenberg J (2000) Making the most of statistical analyses: Improving interpretation and presentation. American Journal of Political Science 44(2): 347-61.

Kristen C and Granato N (2007) The educational attainment of the second generation in Germany: Social origins and ethnic inequality. Ethnicities 7(3): 343-366.

Kristen C, Reimer D and Kogan I (2008) Higher education entry of Turkish immigrant youth in Germany. International Journal of Comparative Sociology 49(2/3): 127-151.

Levels M and Dronkers J (2008) Educational performance of native and immigrant children from various countries of origin. Ethnic and Racial Studies 31(8): 14041425 .

Liebkind K, Mannila S, Jasinskaja-Lahti I, Jaakkola M, Kyntäjä E and Reuter A (2004) Venäläinen, Virolainen, Suomalainen: Kolmen Maahanmuuttajaryhmän Kotoutuminen Suomeen [Russian, Estonian, Finn: The Integration of Three Immigrant Groups in Finland]. Helsinki: Gaudeamus.

Mood C (2010) Logistic regression: Why we cannot do what we think we can do, and what we can do about it. European Sociological Review 26(1): 67-82.

OECD (2004) Learning for Tomorrow's World: First Results from PISA 2003. Paris: Organisation for Economic Co-operation and Development (OECD).

OECD (2006) Where Immigrant Students Succeed - A Comparative Review of Performance and Engagement in PISA 2003. Paris: Organisation for Economic Cooperation and Development (OECD). 
Pohjanpää K, Paananen S and Nieminen M (2003) Maahanmuuttajien Elinolot: Venäläisten, Virolaisten, Somalialaisten ja Vietnamilaisten Elämää Suomessa 2002 [Immigrants' Living Conditions]. Helsinki: Statistics Finland.

Rumbaut RG (2004) Ages, life stages and generational cohorts: Decomposing the immigrant first and second generation in the United States. International Migration Review 38(3): 1160-1205.

Solon G (2002) Cross-country differences in intergenerational earnings mobility. The Journal of Economic Perspectives 16: 59-66.

Statistics Finland (2007) Oppilaitostilastot 2006 [Educational Institutions 2006]. Helsinki: Statistics Finland.

Statistics Finland (2010) Country of Birth according to Age and Gender by Region 1990-2009. Available at:

http://pxweb2.stat.fi/database/StatFin/vrm/vaerak/vaerak_en.asp.

Suarez-Orozco C, Suarez-Orozco MM and Todorova I (2008) Learning a New Land: Immigrant Students in American Society. Cambridge, MA: Belknap Press.

Tomz M, Wittenberg J and King G (2003) CLARIFY: Software for Interpreting and Presenting Statistical Results. Version 2.1. Available at: http://gking.harvard.edu/.

Van de Werfhorst HG and Van Tubergen F (2007) Ethnicity, schooling, and merit in The Netherlands. Ethnicities 7(3): 416-444.

Van Ours JC and Veenman J (2003) The educational attainment of second-generation immigrants in The Netherlands. Journal of Population Economics 16(4): 739-753.

Vanttaja M and Järvinen T (2004) Koulutuksesta ja työstä karsiutuneet. Vailla ammattitutkintoa ja työpaikkaa vuonna 1985 olleiden nuorten myöhemmät elämänvaiheet [The later life of young people out of education and employment in 
1985]. Yhteiskuntapolitiikka 69(5): 472-480.

\section{Appendix}

[Table A1 about here]

[Table A2 about here]

[Table A3 about here]

[Table A4 about here] 
Table 1: Ethnic origin groups and continuation to upper secondary education (2001-5)

\begin{tabular}{|c|c|c|c|c|c|}
\hline \multirow[b]{2}{*}{ Ethnic origin* } & \multicolumn{2}{|c|}{ Data } & \multicolumn{3}{|c|}{ Continuation in upper secondary } \\
\hline & $\mathrm{N}$ & $\begin{array}{c}\% \text { in } \\
\text { population }\end{array}$ & $\begin{array}{c}\text { in general } \\
\text { schools }\end{array}$ & $\begin{array}{c}\text { in } \\
\text { vocational } \\
\text { schools }\end{array}$ & $\begin{array}{c}\text { out of } \\
\text { education }\end{array}$ \\
\hline Russian/Estonian 2nd gen & 525 & 0.4 & 55.5 & 35.7 & 8.9 \\
\hline Russian/Estonian 1st gen & 1254 & 0.8 & 44.4 & 45.7 & 10.0 \\
\hline Ex-Yugoslav & 271 & 0.2 & 23.6 & 61.6 & 14.8 \\
\hline West Asian/North African 2nd gen & 117 & 0.1 & 49.3 & 32.9 & 17.9 \\
\hline West Asian/North African 1st gen & 290 & 0.2 & 45.5 & 36.2 & 18.3 \\
\hline East Asian 2nd gen & 148 & 0.1 & 57.7 & 32.1 & 10.2 \\
\hline East Asian 1st gen & 96 & 0.1 & 45.8 & 34.4 & 19.8 \\
\hline Sub-Saharan African 2nd gen & 108 & 0.1 & 63.0 & 18.5 & 18.5 \\
\hline Sub-Saharan African 1st gen & 249 & 0.2 & 29.7 & 41.0 & 29.3 \\
\hline Other 2nd gen & 112 & 0.1 & 55.5 & 28.7 & 15.9 \\
\hline Other 1st gen & 138 & 0.1 & 32.7 & 48.3 & 19.0 \\
\hline Mixed origin (one Finnish parent) & 588 & 1.5 & 65.1 & 29.0 & 5.9 \\
\hline Other-language Finn & 172 & 0.1 & 57.0 & 28.5 & 14.5 \\
\hline Swedish-language Finn & 4779 & 5.1 & 57.6 & 37.8 & 4.7 \\
\hline Finnish-language Finn & 14,311 & 91.1 & 54.5 & 39.9 & 5.6 \\
\hline Total & 23,158 & 100.0 & 54.6 & 39.7 & 5.8 \\
\hline
\end{tabular}

*defined by parental country of birth 
Table A1. Models of continuing in education versus dropping out

\begin{tabular}{|c|c|c|c|c|c|c|c|c|}
\hline & \multicolumn{4}{|c|}{ Log odds ratios } & \multicolumn{4}{|c|}{ Average marginal effects } \\
\hline & Model 1 & Model 2 & Model 3 & Model 4 & Model 1 & Model 2 & Model 3 & Model 4 \\
\hline \multicolumn{9}{|c|}{ Ethnic origin (defined by parental country of birth, Finnish-speaking Finn as reference) } \\
\hline \multirow[t]{2}{*}{ Russian/Estonian 2nd gen } & $-0.49 * *$ & -0.13 & -0.20 & -0.13 & $-0.032 *$ & -0.007 & -0.012 & -0.007 \\
\hline & $(0.23)$ & $(0.24)$ & $(0.24)$ & $(0.25)$ & $(0.018)$ & $(0.014)$ & $(0.015)$ & $(0.013)$ \\
\hline \multirow[t]{2}{*}{ Russian/Estonian 1st gen } & $-0.62 * * *$ & -0.09 & $-0.21^{*}$ & -0.03 & $-0.044 * * *$ & -0.005 & -0.012 & -0.002 \\
\hline & $(0.10)$ & $(0.12)$ & $(0.12)$ & $(0.12)$ & $(0.009)$ & $(0.007)$ & $(0.007)$ & $(0.006)$ \\
\hline \multirow[t]{2}{*}{ Ex-Yugoslav } & $-1.07 * * *$ & -0.25 & $-0.39 * *$ & -0.04 & $-0.091 * * *$ & -0.015 & $-0.024^{*}$ & -0.002 \\
\hline & $(0.18)$ & (0.19) & $(0.19)$ & $(0.20)$ & $(0.022)$ & $(0.012)$ & $(0.013)$ & $(0.010)$ \\
\hline \multirow[t]{2}{*}{ W Asian/N African 2nd gen } & $-1.29 * * *$ & $-0.64 * *$ & $-0.65 * *$ & -0.43 & $-0.122 * * *$ & $-0.044^{* *}$ & $-0.044^{*}$ & -0.025 \\
\hline & $(0.24)$ & $(0.26)$ & $(0.26)$ & $(0.27)$ & $(0.035)$ & $(0.022)$ & $(0.023)$ & $(0.018)$ \\
\hline \multirow[t]{2}{*}{ W Asian/N African 1st gen } & $-1.32 * * *$ & $-0.45 * * *$ & $-0.47 * * *$ & $-0.37 * *$ & $-0.127 * * *$ & $-0.028 * *$ & $-0.030 * *$ & $-0.021 *$ \\
\hline & $(0.16)$ & $(0.17)$ & $(0.18)$ & $(0.18)$ & $(0.023)$ & $(0.013)$ & $(0.013)$ & $(0.012)$ \\
\hline \multirow[t]{2}{*}{ East Asian 2nd gen } & $-0.64 * *$ & 0.07 & 0.04 & -0.35 & $-0.045^{*}$ & 0.004 & 0.002 & -0.019 \\
\hline & $(0.27)$ & $(0.28)$ & $(0.27)$ & $(0.28)$ & $(0.025)$ & $(0.014)$ & $(0.014)$ & $(0.018)$ \\
\hline \multirow[t]{2}{*}{ East Asian 1st gen } & $-1.42 * * *$ & $-0.64 * *$ & $-0.67 * *$ & $-1.01 * * *$ & $-0.142 * * *$ & $-0.044^{*}$ & $-0.046^{*}$ & $-0.072 * * *$ \\
\hline & $(0.26)$ & $(0.27)$ & $(0.28)$ & $(0.27)$ & $(0.041)$ & $(0.024)$ & $(0.024)$ & $(0.026)$ \\
\hline \multirow[t]{2}{*}{ Sub-Saharan African 2nd gen } & $-1.34 * * *$ & $-0.49 *$ & $-0.49 *$ & -0.38 & $-0.129 * * *$ & -0.031 & -0.031 & -0.021 \\
\hline & $(0.25)$ & $(0.26)$ & $(0.27)$ & $(0.28)$ & $(0.037)$ & $(0.020)$ & $(0.020)$ & $(0.018)$ \\
\hline \multirow[t]{2}{*}{ Sub-Saharan African 1st gen } & $-1.94 * * *$ & $-0.91 * * *$ & $-0.84 * * *$ & $-0.69 * * *$ & $-0.237 * * *$ & $-0.070 * * *$ & $-0.062 * * *$ & $-0.044 * * *$ \\
\hline & $(0.14)$ & $(0.16)$ & $(0.17)$ & $(0.18)$ & $(0.029)$ & $(0.017)$ & $(0.017)$ & $(0.014)$ \\
\hline \multirow[t]{2}{*}{ Other 2nd gen } & $-1.15 * * *$ & $-0.72 * *$ & $-0.77 * * *$ & $-0.66 * *$ & $-0.102 * * *$ & $-0.051 * *$ & $-0.055^{* *}$ & $-0.042 *$ \\
\hline & $(0.26)$ & $(0.28)$ & $(0.28)$ & $(0.30)$ & $(0.035)$ & $(0.026)$ & $(0.026)$ & $(0.023)$ \\
\hline \multirow[t]{2}{*}{ Other 1st gen } & $-1.37 * * *$ & $-0.62 * *$ & $-0.69 * *$ & $-0.63 * *$ & $-0.134 * * *$ & $-0.042 *$ & $-0.048 * *$ & $-0.039 *$ \\
\hline & $(0.23)$ & $(0.26)$ & $(0.27)$ & $(0.30)$ & $(0.035)$ & $(0.022)$ & $(0.024)$ & $(0.023)$ \\
\hline Mixed origin & -0.05 & -0.13 & -0.13 & -0.13 & -0.003 & -0.007 & -0.007 & -0.007 \\
\hline
\end{tabular}




\begin{tabular}{|c|c|c|c|c|c|c|c|c|}
\hline & $(0.23)$ & $(0.23)$ & $(0.23)$ & $(0.24)$ & (0.013) & (0.013) & $(0.013)$ & $(0.013)$ \\
\hline \multirow[t]{2}{*}{ Other language } & $-1.05 * * *$ & $-0.88 * * *$ & $-0.88 * * *$ & $-1.08 * * *$ & $-0.089 * * *$ & $-0.067 * * *$ & $-0.066 * * *$ & $-0.078 * * *$ \\
\hline & $(0.22)$ & $(0.24)$ & $(0.24)$ & $(0.25)$ & $(0.027)$ & $(0.024)$ & $(0.024)$ & $(0.025)$ \\
\hline \multirow[t]{2}{*}{ Swedish-speaking } & $0.20 * * *$ & -0.00 & -0.02 & -0.02 & $0.010 * * *$ & -0.000 & -0.001 & -0.001 \\
\hline & $(0.08)$ & $(0.08)$ & $(0.08)$ & $(0.08)$ & $(0.004)$ & $(0.004)$ & $(0.004)$ & $(0.004)$ \\
\hline \multirow{2}{*}{\multicolumn{2}{|c|}{ Gender (female vs. male) }} & -0.10 & -0.10 & $-0.71 * * *$ & & -0.006 & -0.005 & $-0.037 * * *$ \\
\hline & & $(0.07)$ & $(0.07)$ & $(0.07)$ & & $(0.004)$ & $(0.004)$ & $(0.004)$ \\
\hline \multicolumn{9}{|c|}{ Father's labour force participation (employed as reference) } \\
\hline \multirow[t]{2}{*}{ Unemployed } & & $-0.58 * * *$ & $-0.48 * * *$ & $-0.32 * * *$ & & $-0.035^{* * *}$ & $-0.028 * * *$ & $-0.017 * * *$ \\
\hline & & $(0.10)$ & $(0.11)$ & $(0.11)$ & & $(0.007)$ & $(0.007)$ & $(0.006)$ \\
\hline \multirow[t]{2}{*}{ Outside labour force } & & $-0.25 * *$ & -0.21 & -0.13 & & $-0.013^{*}$ & -0.011 & -0.007 \\
\hline & & $(0.13)$ & $(0.13)$ & $(0.13)$ & & $(0.007)$ & $(0.007)$ & $(0.007)$ \\
\hline \multirow[t]{2}{*}{ Unknown } & & $-0.57^{* * *}$ & $-0.31 * * *$ & $-0.25 * *$ & & $-0.034^{* * *}$ & $-0.017 * *$ & $-0.013 * *$ \\
\hline & & $(0.10)$ & $(0.11)$ & $(0.11)$ & & $(0.007)$ & $(0.007)$ & $(0.006)$ \\
\hline \multicolumn{9}{|c|}{ Mother's labour force participation (employed as reference) } \\
\hline \multirow[t]{2}{*}{ Unemployed } & & $-0.59 * * *$ & $-0.51 * * *$ & $-0.34 * * *$ & & $-0.035 * * *$ & $-0.029 * * *$ & $-0.018^{* * *}$ \\
\hline & & $(0.09)$ & $(0.10)$ & $(0.10)$ & & $(0.007)$ & $(0.006)$ & $(0.006)$ \\
\hline \multirow[t]{2}{*}{ Outside labour force } & & $-0.49 * * *$ & $-0.42 * * *$ & $-0.37 * * *$ & & $-0.028 * * *$ & $-0.023 * * *$ & $-0.019 * *$ \\
\hline & & $(0.13)$ & $(0.13)$ & $(0.13)$ & & $(0.009)$ & $(0.008)$ & $(0.008)$ \\
\hline \multirow[t]{2}{*}{ Unknown } & & $-0.74 * * *$ & $-0.61 * * *$ & $-0.57 * * *$ & & $-0.047 * * *$ & $-0.037^{* * *}$ & $-0.032 * * *$ \\
\hline & & $(0.11)$ & $(0.12)$ & $(0.12)$ & & $(0.009)$ & $(0.009)$ & $(0.008)$ \\
\hline \multicolumn{9}{|c|}{ Parental education (upper secondary education or lower (or unknown) as reference) } \\
\hline \multirow[t]{2}{*}{ Tertiary education } & & $0.83 * * *$ & $0.81^{* * *}$ & $0.28 * * *$ & & $0.041 * * *$ & $0.039 * * *$ & $0.014^{* * *}$ \\
\hline & & $(0.08)$ & $(0.08)$ & $(0.08)$ & & $(0.004)$ & $(0.004)$ & $(0.004)$ \\
\hline \multicolumn{9}{|c|}{ Household composition (two parents, one or two children as reference) } \\
\hline \multirow[t]{2}{*}{ Two parents, three or more children } & & & $-0.21 * *$ & $-0.20 * *$ & & & $-0.010 * *$ & $-0.009 * *$ \\
\hline & & & $(0.08)$ & $(0.09)$ & & & $(0.004)$ & $(0.004)$ \\
\hline
\end{tabular}


One parent, one or two children

One parent, three or more children

Living alone or unknown

Average grade (centered at 7.5)

Constant

$2.82 * * *$

$(0.04)$

$-5070$

10292

Log likelihood

9914

$-0.58 * * *$

$0.37 * * *$

(0.10)

$(0.10)$

$-0.54 * * * \quad-0.30 * *$

(0.14) (0.14)

$-0.97 * * * \quad 0.79 * * *$

(0.18)

(0.18)

1.10***

(0.05)

$3.54 * * *$

(0.09)

$\mathrm{BIC}$

Robust standard errors in parentheses; N 23,158 for all models; $* * * p<0.01, * * p<0.05, * p<0.1$

$\begin{array}{ll}-0.032 * * * & -0.019 * * * \\ (0.006) & (0.005) \\ -0.030 * * * & -0.015 * \\ (0.009) & (0.008) \\ & \\ -0.064 * * * & -0.046 * * * \\ (0.016) & (0.013) \\ & 0.054 * * * \\ & (0.003)\end{array}$

$-0.032 * * * \quad-0.019 * * *$

$-0.030 * * * \quad-0.015 *$

.008)

(0.003) 
Table A2. Models of continuation in education with interactions added

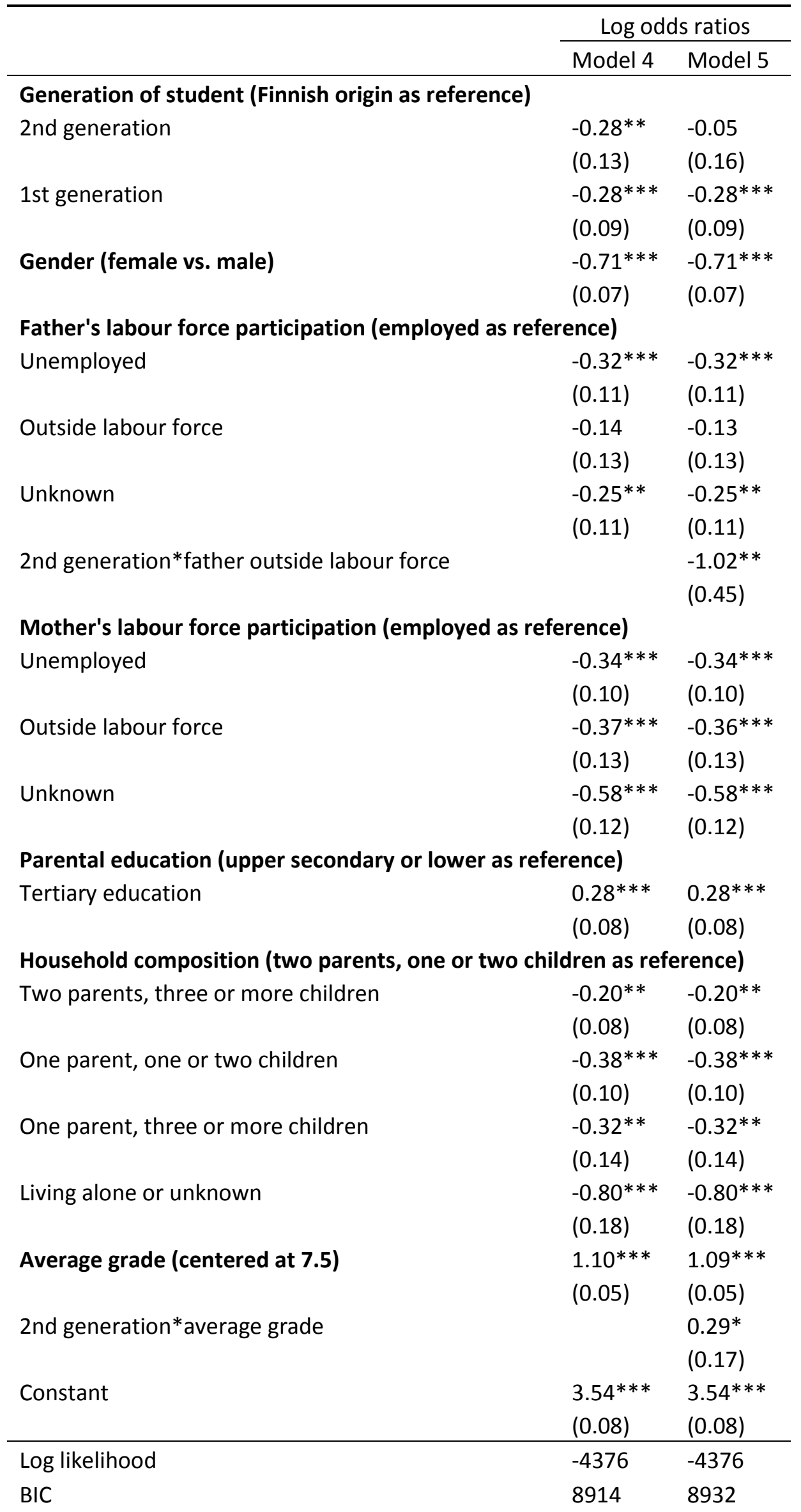


Robust standard errors in parentheses; N 23,158 for all models; *** $p<0.01,{ }^{* *} p<0.05, * p<0.1$ 
Table A3. Models of choice of general upper secondary versus vocational upper secondary school

\begin{tabular}{|c|c|c|c|c|c|c|c|c|}
\hline & \multicolumn{4}{|c|}{ Log odds ratios } & \multicolumn{4}{|c|}{ Average marginal effects } \\
\hline & Model 1 & Model 2 & Model 3 & Model 4 & Model 1 & Model 2 & Model 3 & Model 4 \\
\hline \multicolumn{9}{|c|}{ Ethnic origin (defined by parental country of birth, Finnish-speaking Finn as reference) } \\
\hline \multirow[t]{2}{*}{ Russian/Estonian 2nd gen } & 0.13 & $0.41^{* *}$ & $0.38 * *$ & $0.80 * * *$ & 0.031 & $0.078 * *$ & $0.073 * *$ & $0.092 * * *$ \\
\hline & $(0.14)$ & $(0.18)$ & $(0.18)$ & $(0.17)$ & $(0.033)$ & $(0.034)$ & $(0.034)$ & (0.018) \\
\hline \multirow[t]{2}{*}{ Russian/Estonian 1st gen } & $-0.34 * * *$ & 0.03 & -0.03 & $0.30 * *$ & $-0.084 * * *$ & 0.007 & -0.006 & $0.036 * *$ \\
\hline & $(0.06)$ & $(0.08)$ & $(0.08)$ & $(0.13)$ & $(0.016)$ & $(0.016)$ & $(0.016)$ & (0.015) \\
\hline \multirow[t]{2}{*}{ Ex-Yugoslav } & $-1.27 * * *$ & $-0.68 * * *$ & $-0.71 * * *$ & -0.12 & $-0.300 * * *$ & $-0.133^{* * *}$ & $-0.139 * * *$ & -0.014 \\
\hline & $(0.15)$ & $(0.17)$ & $(0.17)$ & $(0.23)$ & $(0.030)$ & $(0.033)$ & $(0.033)$ & $(0.027)$ \\
\hline \multirow[t]{2}{*}{ W Asian/N African 2nd gen } & 0.09 & $0.75^{* * *}$ & $0.79 * * *$ & $1.77 * * *$ & 0.023 & $0.140 * * *$ & $0.145^{* * *}$ & $0.193 * * *$ \\
\hline & $(0.21)$ & $(0.25)$ & $(0.25)$ & $(0.32)$ & $(0.050)$ & $(0.042)$ & $(0.041)$ & $(0.030)$ \\
\hline \multirow[t]{2}{*}{ W Asian/N African 1st gen } & -0.08 & $0.76 * * *$ & $0.78^{* * *}$ & $1.47^{* * *}$ & -0.020 & $0.141 * * *$ & $0.144 * * *$ & $0.163 * * *$ \\
\hline & $(0.13)$ & $(0.16)$ & $(0.16)$ & $(0.20)$ & $(0.033)$ & $(0.027)$ & $(0.027)$ & $(0.020)$ \\
\hline \multirow[t]{2}{*}{ East Asian 2nd gen } & 0.27 & $1.40 * * *$ & $1.43 * * *$ & $0.88 * * *$ & 0.065 & $0.237 * * *$ & $0.240 * * *$ & $0.100 * * *$ \\
\hline & $(0.21)$ & $(0.22)$ & $(0.21)$ & $(0.27)$ & $(0.047)$ & (0.029) & $(0.028)$ & (0.029) \\
\hline \multirow[t]{2}{*}{ East Asian 1st gen } & -0.02 & $0.89 * * *$ & $0.91 * * *$ & 0.32 & -0.006 & $0.163 * * *$ & $0.164 * * *$ & 0.038 \\
\hline & $(0.23)$ & $(0.26)$ & $(0.26)$ & $(0.32)$ & $(0.057)$ & $(0.043)$ & $(0.042)$ & $(0.037)$ \\
\hline \multirow[t]{2}{*}{ Sub-Saharan African 2nd gen } & $0.91 * * *$ & $1.73 * * *$ & $1.81^{* * *}$ & $2.84 * * *$ & $0.196 * * *$ & $0.277 * * *$ & $0.285^{* * *}$ & $0.283^{* * *}$ \\
\hline & $(0.25)$ & $(0.28)$ & $(0.28)$ & $(0.35)$ & $(0.045)$ & $(0.031)$ & $(0.030)$ & $(0.026)$ \\
\hline \multirow[t]{2}{*}{ Sub-Saharan African 1st gen } & $-0.63 * * *$ & $0.36^{*}$ & $0.44^{* *}$ & $1.24^{* * *}$ & $-0.157^{* * *}$ & $0.069 *$ & $0.083^{* *}$ & $0.139 * * *$ \\
\hline & $(0.15)$ & $(0.19)$ & $(0.19)$ & $(0.22)$ & $(0.037)$ & $(0.036)$ & $(0.036)$ & (0.023) \\
\hline \multirow[t]{2}{*}{ Other 2nd gen } & 0.35 & $0.81 * * *$ & $0.81^{* * *}$ & $1.28 * * *$ & $0.082^{*}$ & $0.150 * * *$ & $0.148 * * *$ & $0.144^{* * *}$ \\
\hline & $(0.22)$ & $(0.26)$ & $(0.26)$ & $(0.34)$ & $(0.050)$ & $(0.043)$ & $(0.043)$ & $(0.035)$ \\
\hline \multirow[t]{2}{*}{ Other 1st gen } & $-0.70 * * *$ & -0.15 & -0.17 & 0.14 & $-0.174 * * *$ & -0.030 & -0.033 & 0.016 \\
\hline & $(0.23)$ & $(0.26)$ & $(0.25)$ & $(0.28)$ & $(0.055)$ & $(0.052)$ & $(0.050)$ & $(0.033)$ \\
\hline Mixed origin & $0.50 * * *$ & $0.35^{* *}$ & $0.35^{* *}$ & $0.68 * * *$ & $0.115^{* * *}$ & $0.068 * *$ & $0.068 * *$ & $0.079 * * *$ \\
\hline
\end{tabular}




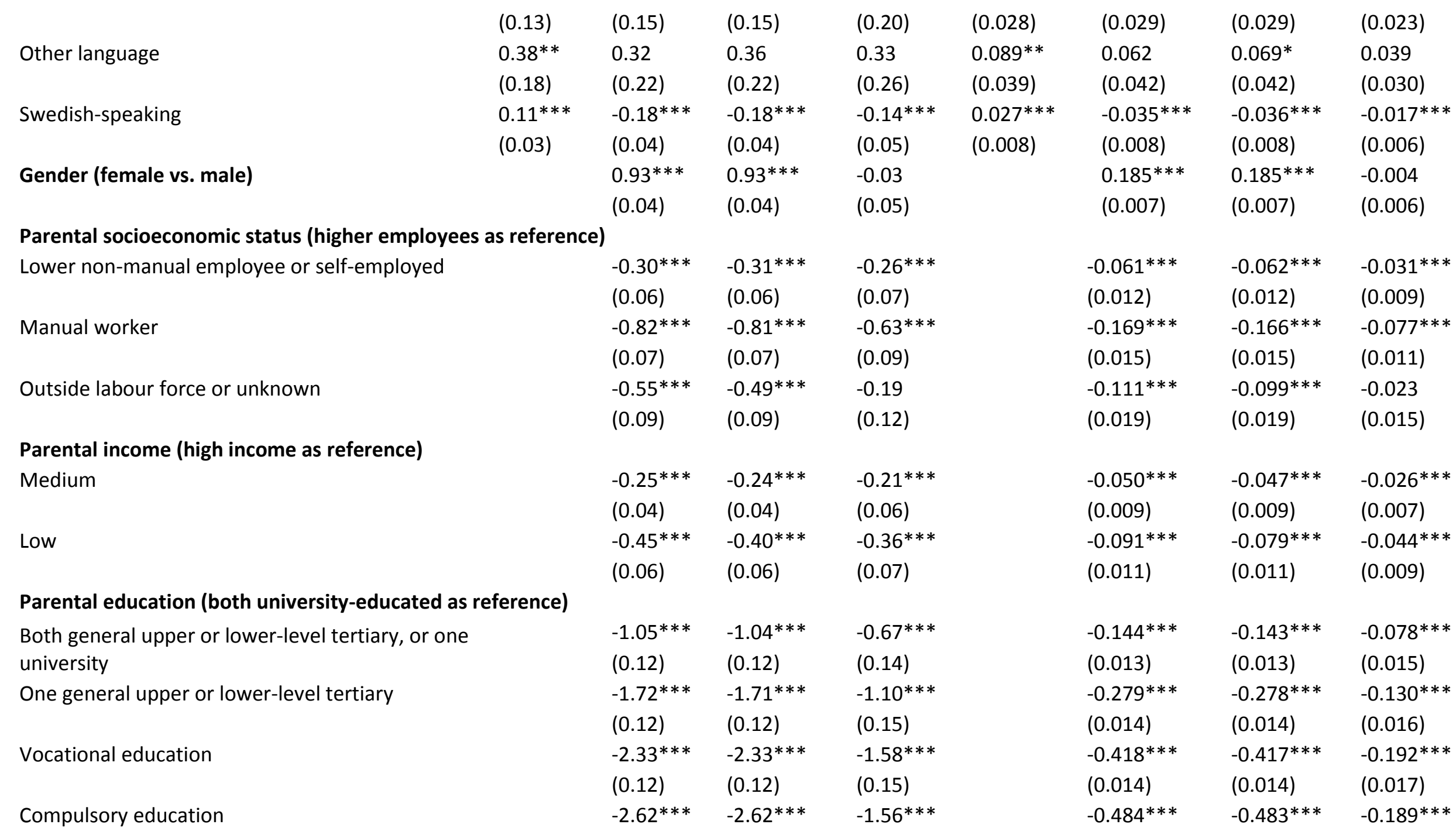




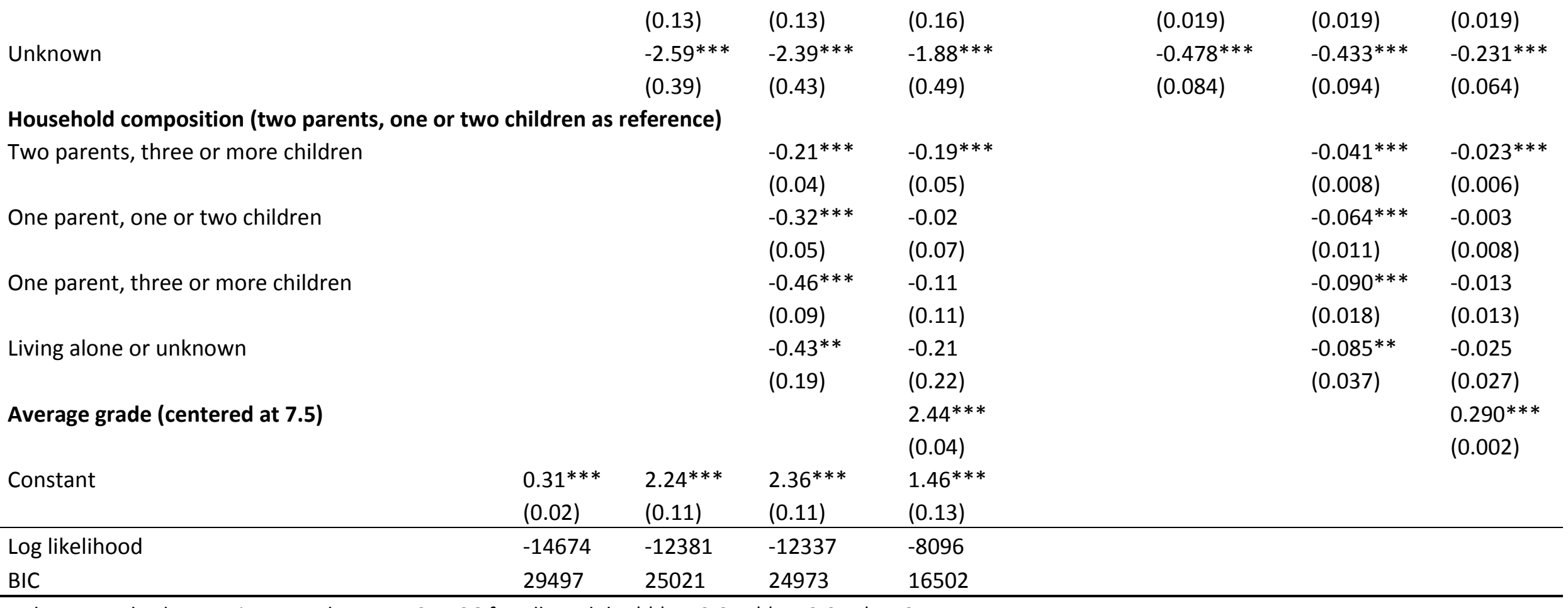

Robust standard errors in parentheses; N 21,596 for all models; ${ }^{* * *} p<0.01,{ }^{* *} p<0.05,{ }^{*} p<0.1$ 
Table A4. Models of choice of academic upper secondary with interactions added

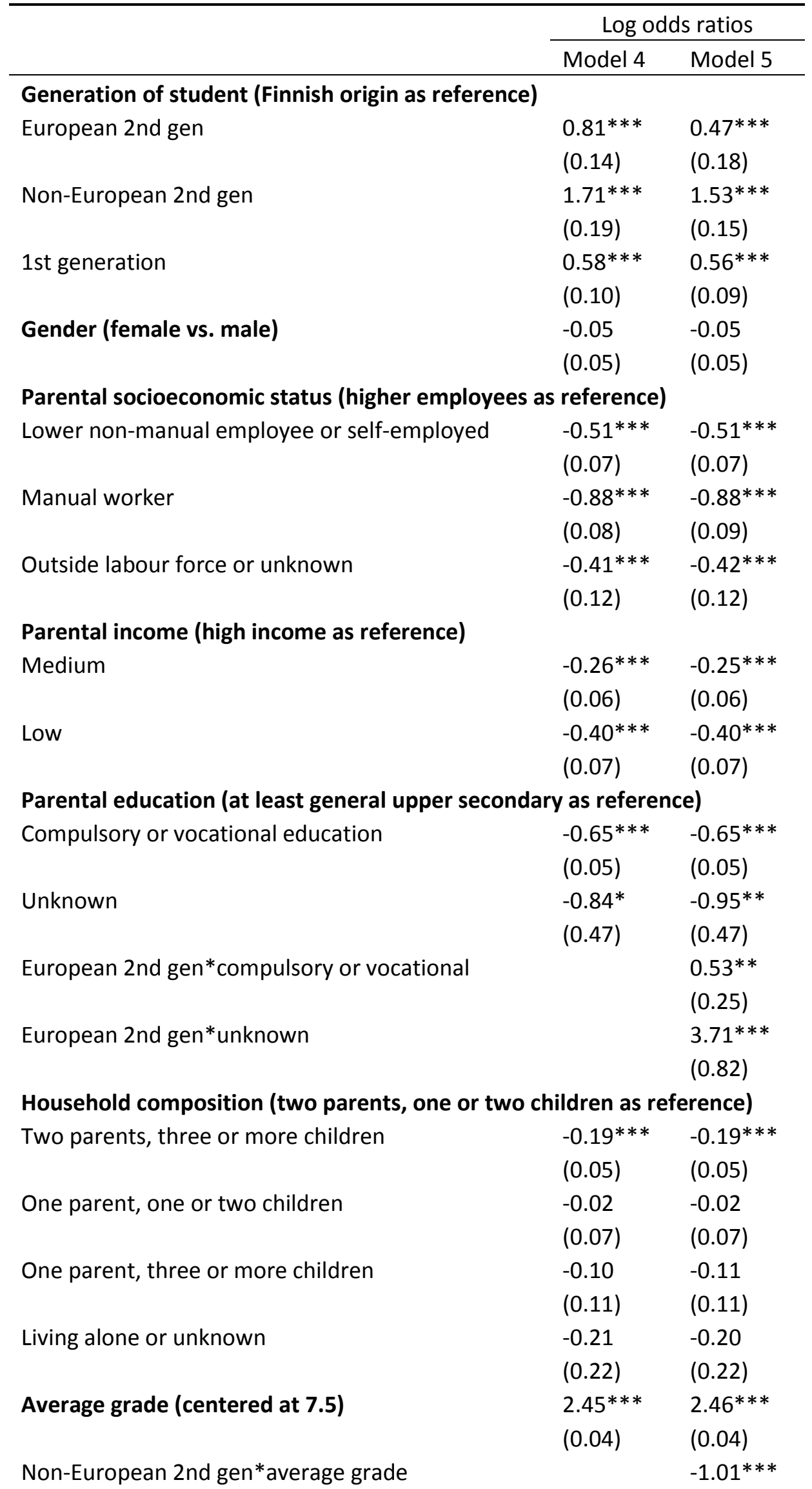


$(0.22)$

1st gen*average grade

$-0.48 * * *$

$(0.15)$

Constant

$0.80 * * *$

$0.80 * * *$

\begin{tabular}{lcc} 
& $(0.06)$ & $(0.06)$ \\
\hline Log likelihood & -8160 & -8156 \\
BIC & 16489 & 16521 \\
\hline
\end{tabular}

Robust standard errors in parentheses; N 21,596 for all models; *** $p<0.01, * * p<0.05, * p<0.1$ 


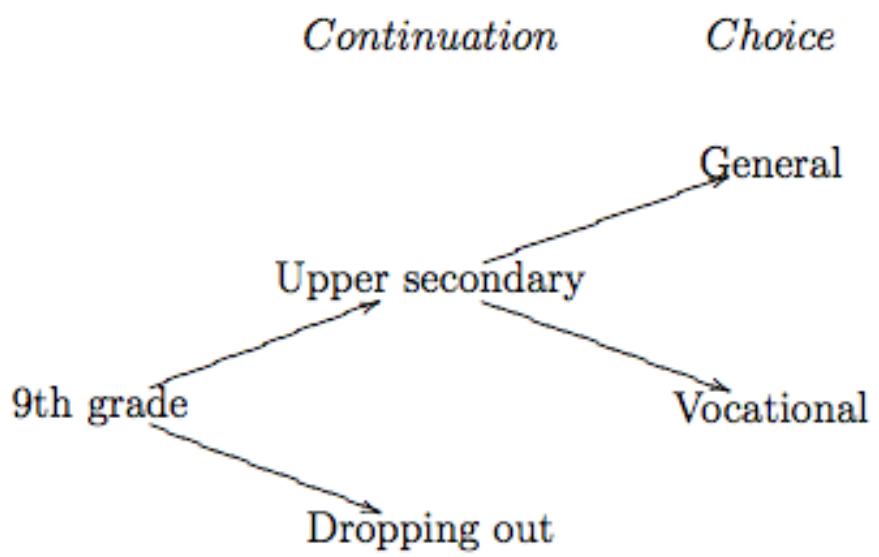

Figure 1. The two parts of the continuation decision 


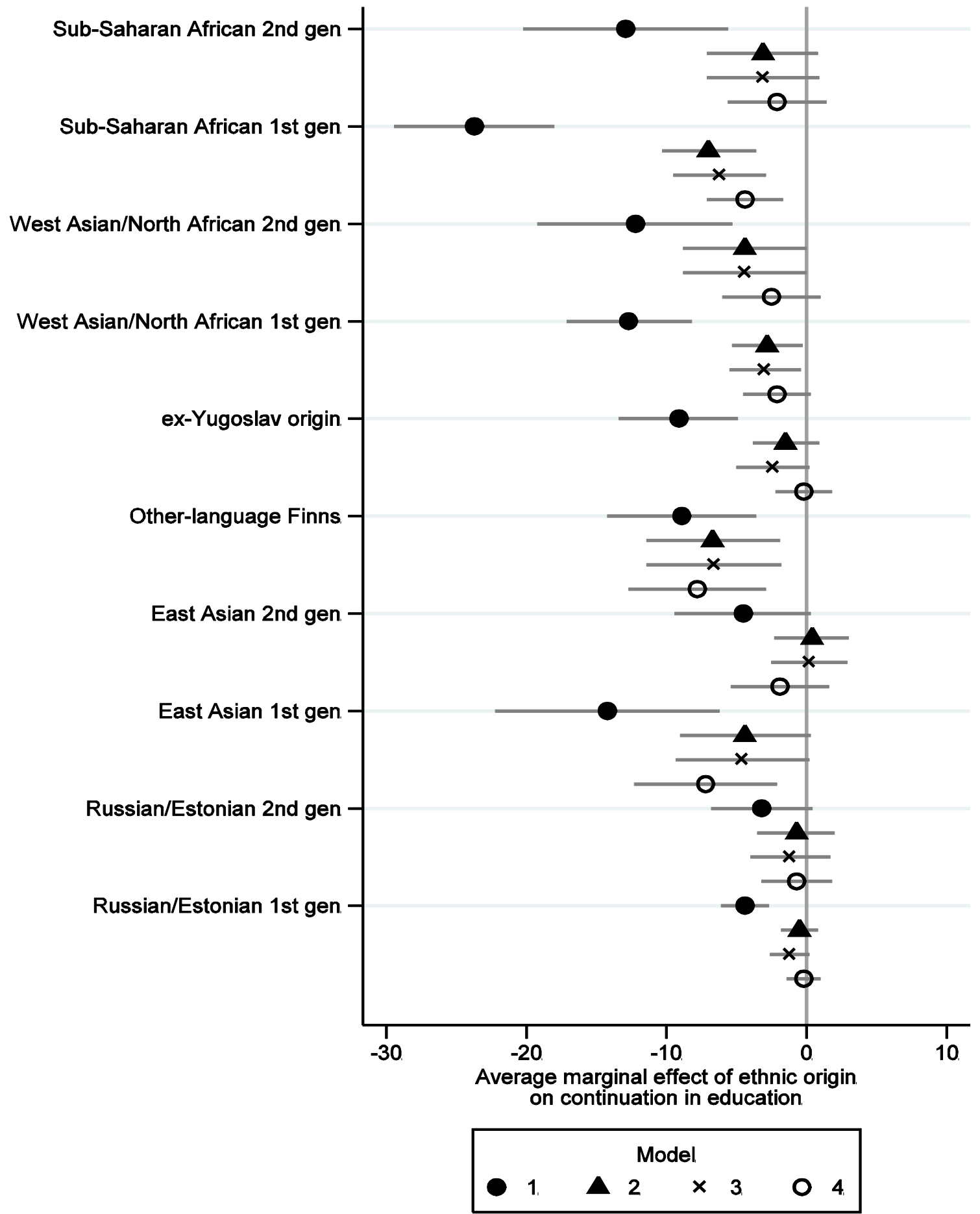

$95 \%$ confidence intervals included around estimates

Figure 2. Effect of ethnic origin on continuation in education in different models, results as average marginal effects 


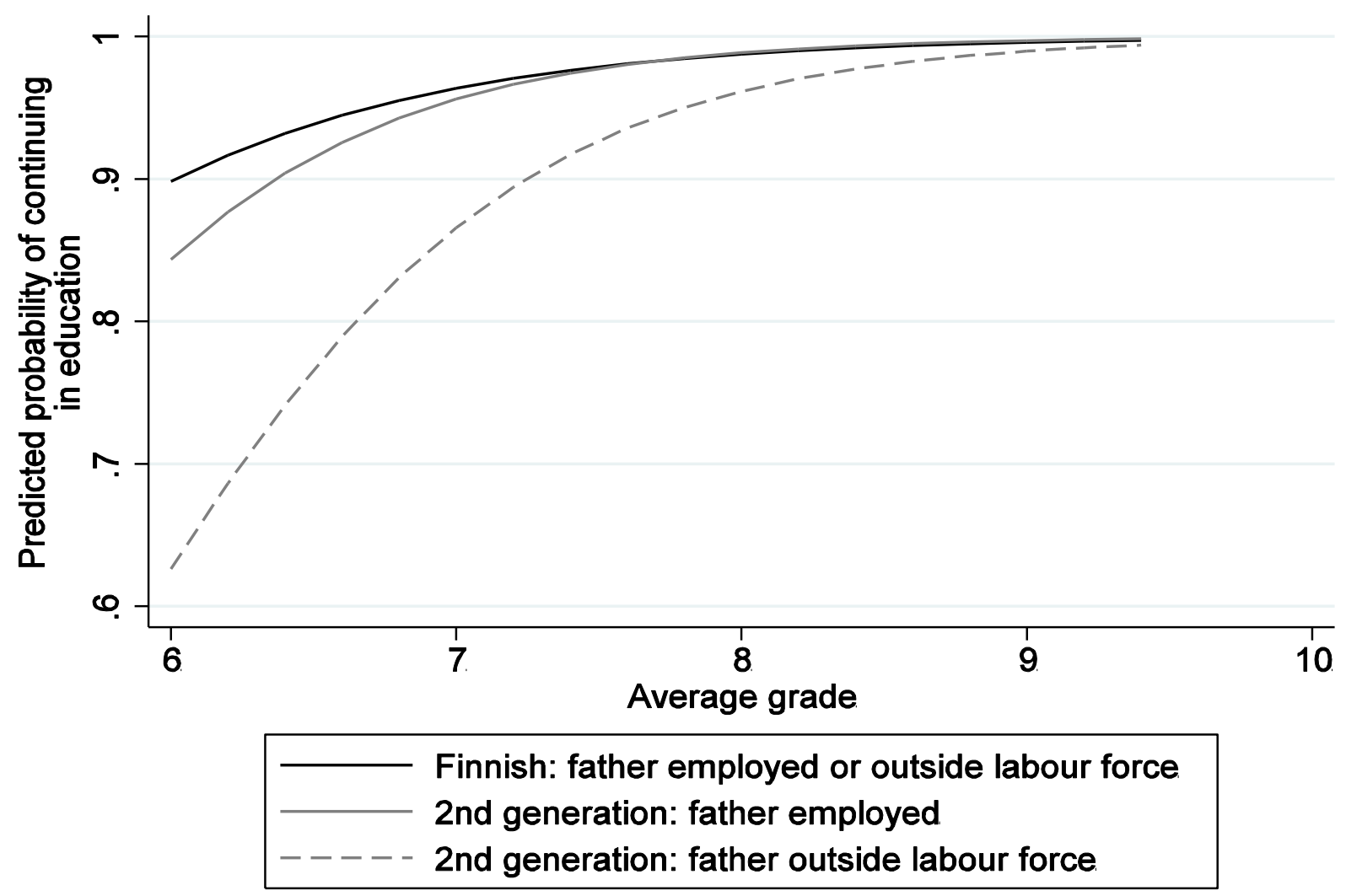

Figure 3. Effect of grades and father's labour force participation on continuation in education for different generations, predicted probabilities (range of grades 6-9.5, male student who is living in a household with two adults and a maximum of two children, and who has an employed mother, a father who is employed or outside the labour force, and at least one parent with tertiary education) 


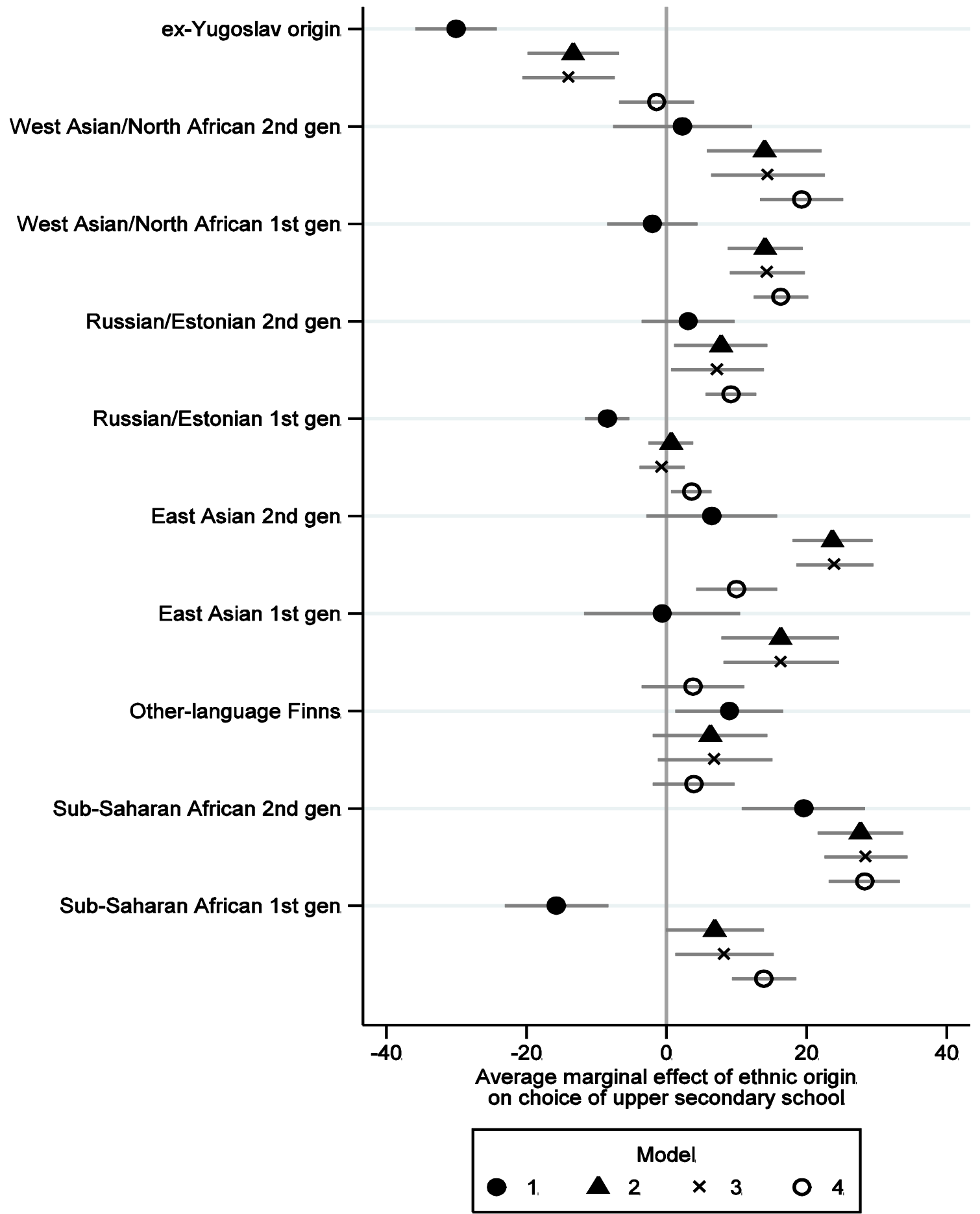

95\% confidence intervals included around estimates

Figure 4. Effect of ethnic origin on choice of general versus vocational upper secondary school in different models, results as average marginal effects 

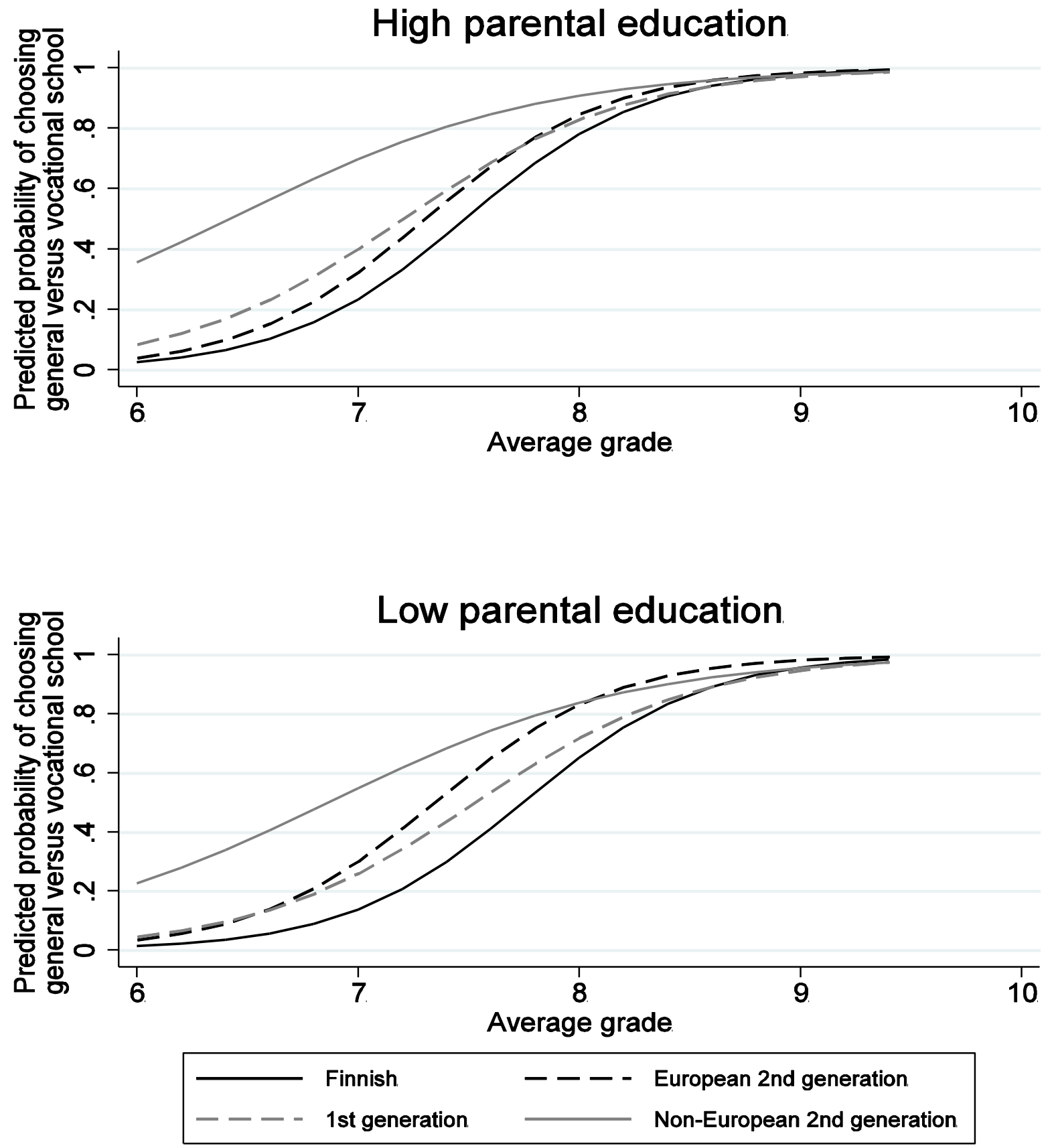

Figure 5. Effect of grades and parental education on choice of general versus vocational upper secondary school for different generations, predicted probabilities (range of grades is 6-9.5, male student living in a household with two adults and a maximum of two children, whose parents have a medium income and are lower-level employees or self-employed) 